\title{
Neogene woods from western Peruvian Amazon and palaeoenvironmental interpretation
}

\author{
DENISE PONS \& DARIO DE FRANCESCHI
}

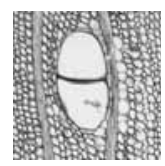

\begin{abstract}
Vegetation dynamics in the Western Amazonian Basin are studied using knowledge of palaeobotany. Fossil wood specimens from eroded sediments on the banks of the Amazon in the Iquitos region of Peru come from layers dated as Middle Miocene to Pliocene. Samples include branch fragments or entire tree trunks either as compressed lignites or silicified stems. The wood can be assigned to modern genera of various families still present in the South American flora. Samples from the Middle Miocene Pebas Formation show affinities with taxa now occurring in rain forests: Anacardium (Anacardiaceae), Calophyllum (Clusiaceae), Buchenavia and Terminalia (Combretaceae), Andira / Hymenolobium (Fabaceae), Humiriastrum (Humiriaceae), Cariniana and Eschweilera (Lecythidaceae), Guarea (Meliaceae) and Mimosaceae, which indicates that part of the Recent Amazon Basin flora pre-dates contact with North America. Growth rings are absent or indistinct in the fossils, a characteristic feature of low-elevation rain forests. The fossil assemblage evokes "Hylaea Amazonia" and especially the "terra firme" forests of the modern Amazon delta and surroundings. Fossil wood samples from the Pliocene Amazonas Formation resemble Cedrela (Meliaceae) and are semi ring-porous. The Cedrela wood occurence shows a vegetation change between mid-Miocene and now in the western Amazon Basin. - Key words: Peru, Iquitos, Pebas Formation, Middle Miocene, Pliocene, Amazonas Formation, fossil wood, Angiosperms, palaeoenvironment.
\end{abstract}

PONS, D. \& DE FRANCESCHI, D. 2007. Neogene woods from western Peruvian Amazon and palaeoenvironmental interpretation. Bulletin of Geosciences 82(4), 343-354 (6 figures, 1 table). Czech Geological Survey, Prague. ISSN 1214-1119. Manuscript received April 16, 2007; accepted in revised form September 17, 2007; issued December 31, 2007. • DOI 10.3140/bull.geosci.2007.04.343

Denise Pons, Paléobiodiversité et Paléoenvironnements, UMR 5143 CNRS-UPMC, Laboratoire Paléobotanique et Paléoécologie, 12 rue Cuvier 75005 Paris, France; dpons@snv.jussieu.fr •Dario De Franceschi, Paléobiodiversité et Paléoenvironnements, UMR 5143 CNRS-MNHN Département Histoire de la Terre, CP38, 8 rue Buffon, 75005 Paris, France; dariodf@mnhn.fr

The Amazon Basin is the largest sedimentary basin in the world and harbours the most extensive tropical forest and the highest biodiversity (Groombridge 1992, Davis et al. 1997). Although the Miocene Pebas Formation of northeastern Peru has been investigated in earlier palaeontological studies, the history of the flora dynamics in the Western Amazonian basin is still controversial. Different hypotheses about the initial environmental conditions for this modern forest have been proposed. The present biodiversity is seen either as a continuation of the Neogene forest (Hooghiemstra \& Hammen 1998), or as being recently established after the latest geological structuring of the basin (Campbell 1996, Balée 2000). The present study is a palaeobotanical contribution to a multidisciplinary project on the Neogene evolution of the Amazon Basin.

Despite some palynological studies (Hoorn 1993, 1994), the palaeobotany of the western Peruvian Amazon is still poorly known. We explored the Iquitos and Attalaya regions of Peru in 2004 and 2005. From the eroded sedi- ments of the banks of the Amazon and its tributaries (Fig. 1), we collected numerous fossil wood samples dating from Middle Miocene to Pliocene. The sediments were produced during the Andes uplift; the network of rivers transported and deposited sand, clay and plant parts as well as dead animals into the Amazonian basin. The fossil samples from the Iquitos were branch fragments or entire tree trunks up to 1 meter in diameter and 5 meters in length, carried by the river, as seen nowadays in the Amazon, especially after the rainy season. The outcrops along the Amazon River also provided fossil vertebrates, molluscs and amber with insect and spore inclusions (Antoine et al. 2006).

As plants are excellent tools for reconstructing palaeoclimate and palaeoenvironment, especially through comparison with the modern flora, the study of fossil woods from the Iquitos area can shed new light on past floral composition and past environment and climate of the Neogene Amazon Basin. Fossil wood samples from the Attalaya 


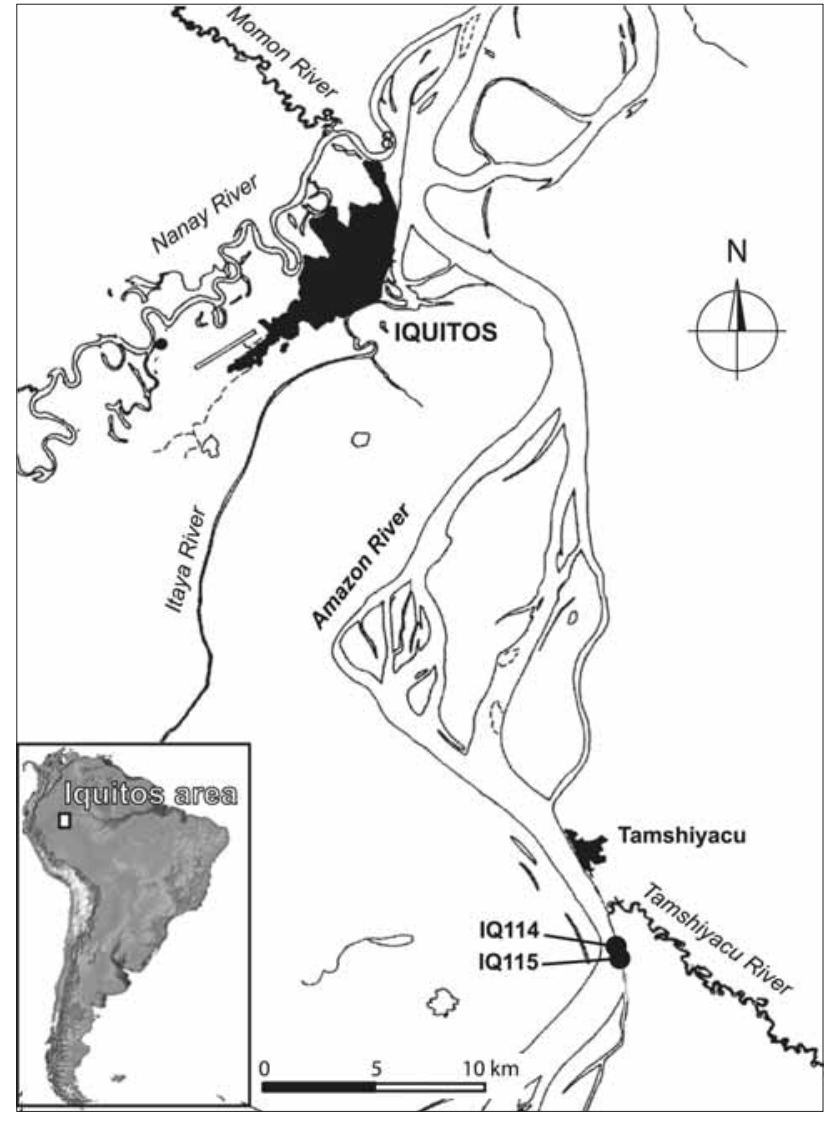

Figure 1. The Iquitos region of Peru and the location of the fossil wood outcrops IQ114 and IQ115.

area are also under study, and this survey will provide new information about the origins and development, and palaeoenvironments of vegetations in the Amazonian Basin.

\section{Material and methods}

In the Iquitos region (Fig. 1), fossil woods are found as lignites, more or less compressed by the sediment weight and/or as silicified samples. Material from the Attalaya region, still being studied, comprises numerous and well preserved silicified wood samples mainly reworked from a recent layer that is still not precisely identified and dated. Lignite specimens are also numerous and in situ in the sediments in that region, but their anatomy is generally badly preserved because they show a partial transformation as vitrain.

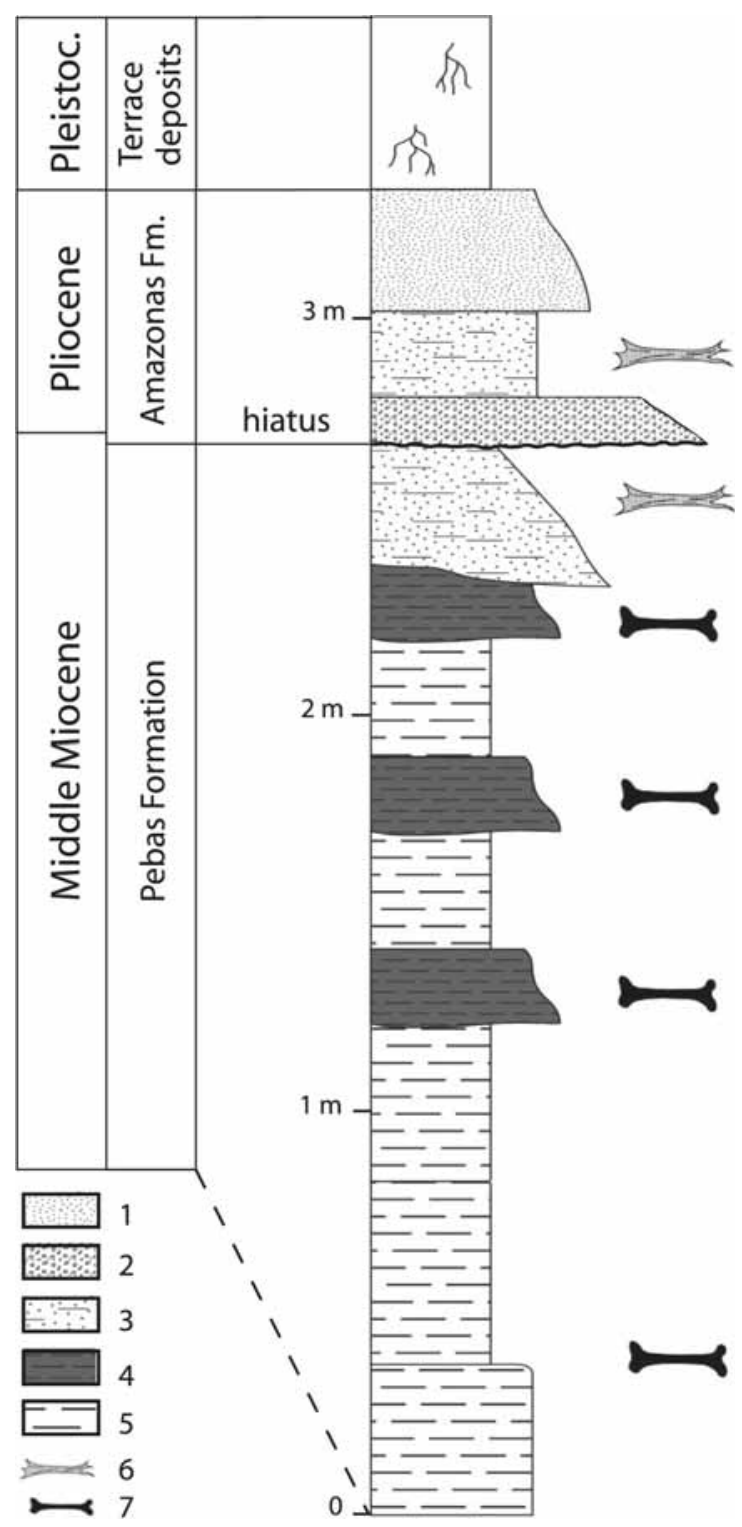

Figure 2. Section of the Amazon river bank at the outcrop IQ115 (modified from N. Espurt, pers. comm. and interpreted after Roddaz et al. 2005, p. 102, fig. 11). 1 - sandy layers, 2 - conglomerates, 3 - clayey sandy layers, 4 - clayey lignite layers, 5 - clayey layers, 6 - fossil wood, 7 - vertebrate remains.

This paper describes some 34 samples (IQW26-IQW59) collected from a site close to the village Tamshiyaku during fieldwork in 2004. Most samples come from a lignite layer in the upper part of the Pebas Formation; a few come

Figure 3. Clusiaceae - Combretaceae. $\bullet$ A - Calophyllum brasiliense Camb. (living species): cross section showing solitary vessels in radial rows with both confluent and vasicentric parenchyma surrounding the vessels. $\bullet \mathrm{B}, \mathrm{C}-\mathrm{cf}$. Calophyllum. $\bullet \mathrm{B}-$ cross section. $\bullet \mathrm{C}-$ tangential section with typical uniseriate rays. $\bullet$ D - cf. Buchenavia, cross section. $\bullet \mathrm{E}-\mathrm{H}-\mathrm{cf}$. Terminalia (type 1$) \bullet \mathrm{E}-$ cross section. $\bullet \mathrm{F}-$ tangential section showing uniseriate rays with crystals $\bullet \mathrm{G}$ - intervessel pits. $\mathrm{H}$ - prismatic crystals in heterocellular rays (radial section). $\bullet$ Scale bars: $\mathrm{A}, \mathrm{B}, \mathrm{D}, \mathrm{E}-1 \mathrm{~mm}, \mathrm{C}, \mathrm{H}-100 \mu \mathrm{m}, \mathrm{F}-500 \mu \mathrm{m}$, $\mathrm{G}-20 \mu \mathrm{m}$. 

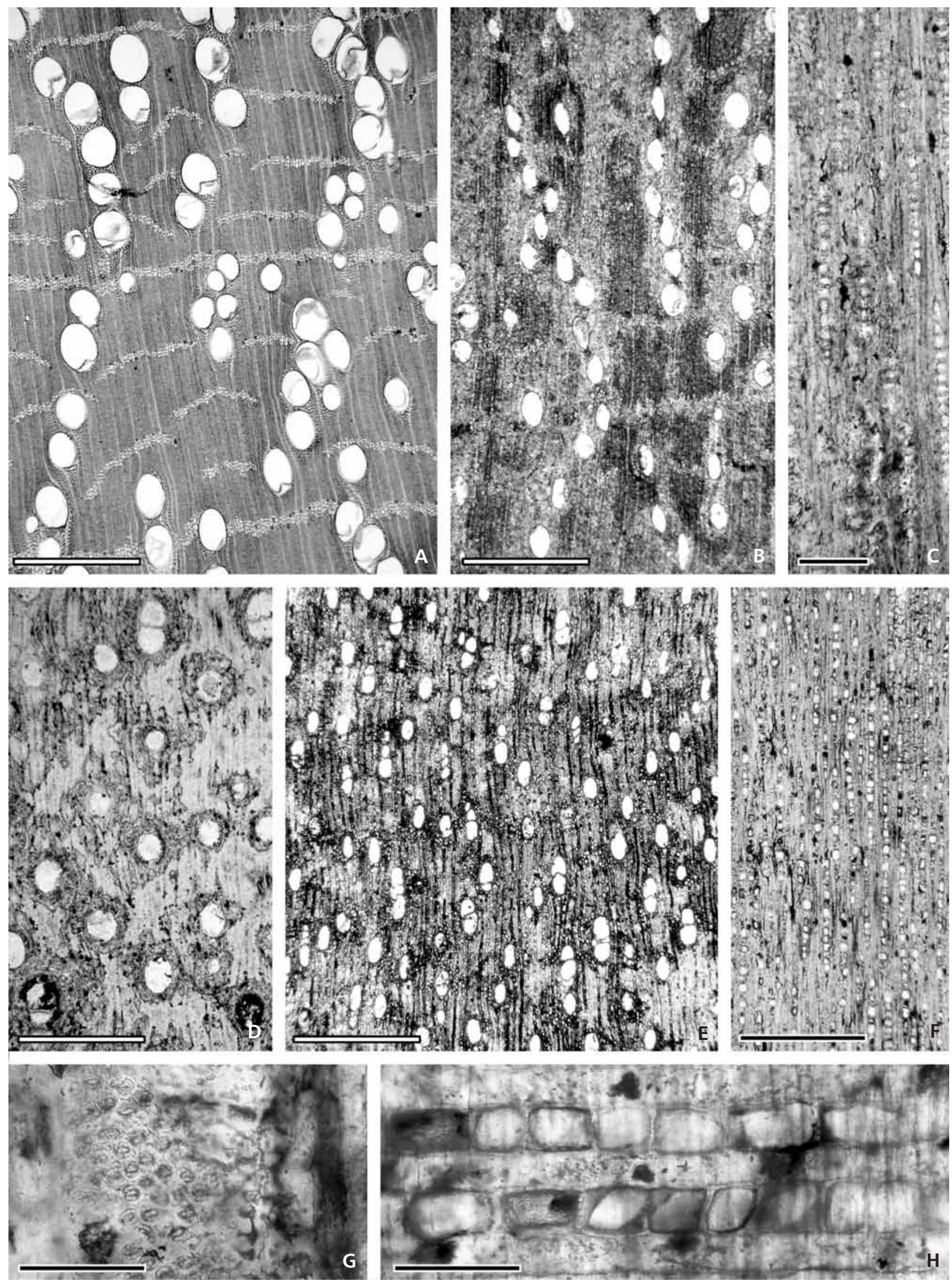
from the Amazonas Formation (Pliocene) (Roddaz et al. 2005, N. Espurt, pers. comm.; Fig. 2). Wood specimens were measured in the field, and the diameter of the trunks and branches were also measured, or estimated from the morphology and anatomy of the fragments. Most woods are trunks or trunk parts with regular, long, straight shapes. Sub-samples were collected from silicified specimens using burin and a hammer. For less mineralized specimens (lignite and waterlogged Pliocene woods), sampling was done with the help of a saw or a cutter. Sections were prepared after embedding in polyester resin for lignite and waterlogged samples and mounted in Canada balsam. Sections are deposited in the fossil plants collection of the Muséum national d'Histoire naturelle of Paris (MNHN). The botanical affinities were determined with the help of literature on South American wood, e.g., Record (1943a-c, 1944a-c), Hess (1946), Pereira \& Mainieri (1957), Kribs (1968), Record \& Hess (1972), Dechamps (1979, 1980, 1985), Détienne et al. (1982), Détienne (1983), Mainieri \& Chimero (1989), but also with more general references such as Metcalfe \& Chalk (1950), Ilic (1991), and the internet database InsideWood (2004 - onwards).

\section{Wood characters and botanical affinities}

Among the 34 fossil wood samples from the Tamshiyaku outcrops, we observed only angiosperm taxa. This identification is based on the microscopic anatomy of these specimens. For descriptions, we used hardwood standardised characters by Wheeler et al. (1989).

Some wood samples from the Pebas Formation can be assigned to extant genera of families, which are present or even endemic in the modern South American flora (Table 1). The following taxa were recognised: Anacardium (Anacardiaceae), Calophyllum (Clusiaceae), Buchenavia and Terminalia (Combretaceae), Hymenolobium (Fabaceae), Humiriaceae. Cariniana, Eschweilera and another undetermined (Lecythidaceae), Guarea (Meliaceae), Samanea/Pseudosamanea (Mimosaceae, Ingeae). Below some diagnostic characters of the more significant taxa are given.

\section{Anacardiaceae}

One specimen is characterised by indistinct growth rings, few and scattered vessels, solitary and in radial groups of
$2-3$, simple perforation plates, intervessel pits $10-12 \mu \mathrm{m}$ in diameter, vasicentric - aliform parenchyma, and numerous 1-2 seriate slightly heterocellular rays with prismatic crystals. This wood resembles Anacardium Lindl., especially A. excelsum (B. \& B.) Skeels.

\section{Clusiaceae}

Figure 3A-C

One specimen is characterised by exclusively solitary vessels in a diagonal pattern, medium to large in diameter; intervessel pits are small $(4.5-6 \mu \mathrm{m})$, vasicentric tracheids present, apotracheal parenchyma in broken to continuous tangential bands of 3-6 cells wide with prismatic crystals; heterocellular uniseriate rays, vessel-ray pits large and simple with reduced borders. This wood resembles the genus Calophyllum L., and has characteristics seen in Calophyllum brasiliensis Camb.

Another specimen shows affinities with Clusacieae, but unlike the previous one has abundant tyloses, regularly spaced apotracheal parenchyma band of 5-6 cells wide, and 2-4 seriate, homocellular rays.

\section{Combretaceae}

Figure 3D-H

Three specimens have features seen in Combretaceae and could be assigned to the morphotaxa Terminalioxylon (Schönfeld) Mädel-Angeliewa \& Müller-Stoll emend.

Two of them are close to the modern genus Terminalia L. The first one is characterised by vessels both solitary and in radial groups of 2-4, of medium diameter, vestured intervessel pits, vasicentric to aliform parenchyma with short wings and confluent bands connecting 2-3 pores, uniseriate heterocellular rays with large and rhomboidal crystals, completely filling a tangentially enlarged, radial series of ray cells (as described by Vliet 1979). This wood (type 1, Fig. 3E-H) resembles the modern T. amazonia (Gmel.) Exell.

The second specimen differs in its parenchyma, which is aliform and in wavy tangential lines, and growth rings slightly marked by marginal parenchyma bands of 1 to 3 cells wide. Prismatic crystals occur in the chambered axial parenchyma cells. This structure (type 2) resembles the $T$. tarapotensis type.

Figure 4. Lecythidaceae. $\bullet$ A-D - cf. Eschweilera. $\bullet$ A - cross section showing narrowly banded parenchyma. $\bullet$ B - tangential section. $\bullet$ C - potential growth ring limit weakly marked by a wider fibre band without parenchyma. $\bullet \mathrm{D}-$ intervessel pits. $\bullet \mathrm{E}-\mathrm{G}-\mathrm{cf}$. Cariniana. $\bullet \mathrm{E}-\mathrm{cross}$ section showing numerous apotracheal parenchyma lines; growth rings indistinct. $\bullet \mathrm{F}$ - tangential section with uni- biseriate rays. $\bullet \mathrm{G}-$ Cariniana domestica Mart. (living species), cross section showing a fibre band without parenchyma lines, potentially corresponding to a growth ring limit. $\bullet$ Scale bars: A, E, G -1 mm, $\mathrm{B}, \mathrm{F}-200 \mu \mathrm{m}, \mathrm{C}-500 \mu \mathrm{m}, \mathrm{D}-20 \mu \mathrm{m}$. 

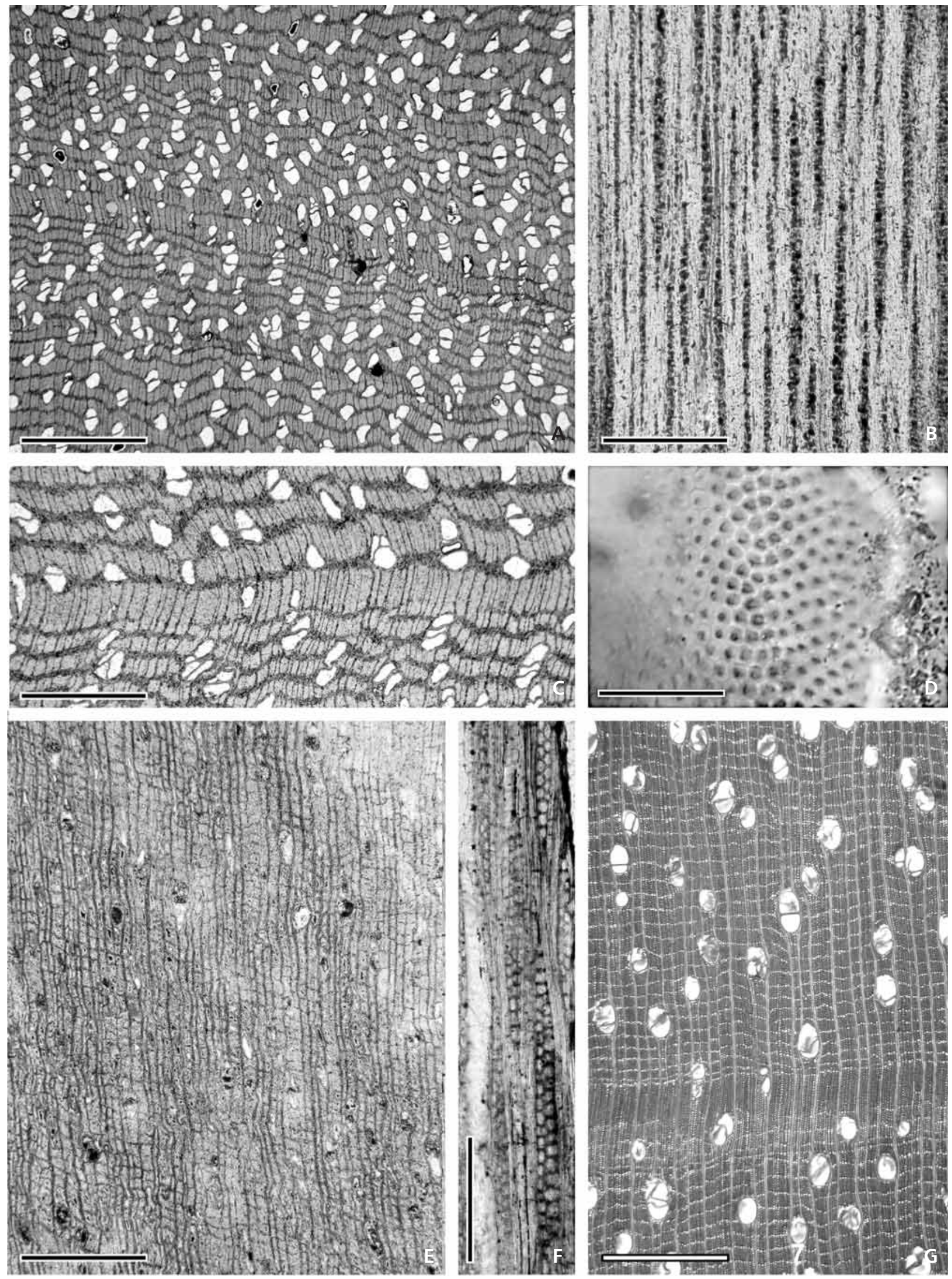
The third specimen presents the following characters: vessels diffuse, solitary and in radial multiple of 2, 4, often including some narrow vessels; presence of tyloses; intervessel pits alternate round to elongate; paratracheal, slightly aliform parenchyma (Fig. 3D), uni-biseriate heterocellular rays, with cells with large solitary rhomboidal crystals, completely filling the cells, more or less isodiametric in horizontal rows. This combination of features is usually found in the genus Buchenavia, and particularly in the species Buchenavia grandis (Détienne 1983).

\section{Humiriaceae}

The three samples assigned to this family are characterised by their solitary vessels with scalariform perforation plates with 15-20 bars; parenchyma diffuse-in-aggregates, fibres with bordered pits, chambered crystalliferous parenchyma, and heterocellular rays. These fossils have features seen in the modern genera Humiria Jaume St-Hil. and Humeriastrum (Urb.) Cuatrec.

\section{Lecythidaceae \\ Figure $4 \mathrm{~A}-\mathrm{G}$}

Four samples resemble Lecythidaceae - Lecythidoideae (Lens et al. 2007). The first sample has indistinct growth rings, vessels solitary and in radial groups of 2-3, intervessel pits of medium size, apotracheal parenchyma in tangential lines of 1-2 cells wide forming a fine reticulum with the rays; rays are (uni-) biseriate and homocellular. Two types of vessel-ray pits are present (few simple pits, or pits oval with more or less reduced borders). This wood is close to Cariniana Casar (Fig. 4E, F), especially the modern species $C$. domestica Mart. (Fig. 4G).

Another sample seems to be close to Eschweilera Mart. because of its parenchyma which occurs in broad continuous tangential bands and homocellular, bi- triseriate rays (Fig. 4A-D). The two other samples remain undetermined.

\section{Leguminoseae}

The wood anatomy of 3 samples could be related to the super family of the Leguminoseae, but we could only identify some to subfamily.

\section{Leg. - Fabaceae}

Figure 5A-E

One wood sample is assigned to this family. It has vessels mainly solitary or in radial multiple of 2-5 or in clusters with medium-sized vestured intervessel pits. Axial parenchyma (2) 3-4 cells per strand (Fig. 5B), are vasicentric, aliform, confluent to banded forming wavy to almost straight, irregular, tangential bands and in seemingly marginal bands. Paratracheal parenchyma are bordered by crystals in chambered fibres and axial parenchyma; rays homocellular uni- triseriate; fibres thick walled and nonseptate. This combination of features is frequent in Andira Juss. and Hymenolobium Benth genera.

\section{Leg. - Mimosaceae}

The one sample assigned to this family has vessels solitary or in radial groups of 2-3, medium-sized intervessel pits; axial parenchyma vasicentric aliform and confluent, crystals in scattered chambered axial parenchyma cells; non septate fibres, with common isolated crystalliferous cells; homocellular, uniseriate rays with locally biseriate portions, mostly unstoried, but irregularly storied in places. These characters are found in the Ingeae tribe/ Abarema alliance (Evans et al. 2006). However, the Dimorphandra group, tribe of Caesalpiniae show strinking similarities.

\section{Meliaceae \\ Figure 6A-H}

Some samples from the Miocene Pebas Formation have indistinct or slightly distinct growth rings, marked by marginal tangential apotracheal parenchyma bands. They have vessels evenly distributed, solitary or in radial group of $2-5$, intervessel pits minute; parenchyma vasicentric or aliform to confuent and sometimes crystalliferous, forming wavy tangential bands, and homocellular bi- triseriate rays. These are characteristics of the genus Guarea Allem. ex L. (Fig. 6A-C).

There are two samples from the Pliocene Amazonas Formation that are semi- to ring porous and are assigned to the Meliaceae. They have large earlywood vessels in a single tangential row, associated with a wide band of initial parenchyma, vessel diameter decreases towards the

Figure 5. Leguminosae \& Incertae sedis. • A-E - cf. Hymenolobium. • A - cross section showing large aliform vasicentric and confluent parenchyma, forming wavy tangential bands. $\bullet \mathrm{B}$ - fibres with very thick walls. $\bullet \mathrm{C}$ - tangential section with all elements storied. $\bullet \mathrm{D}-$ detail showing crystals in chambered parenchyma cells. $\bullet \mathrm{E}$ - vestured intervessel pits. $\bullet \mathrm{F}, \mathrm{G}-$ Incertae sedis (cf. Meliaceae). $\bullet \mathrm{F}-$ cross section with normal vertical canals (arrows) in tangential line. $\bullet \mathrm{G}-$ tangential section showing homocellular pluriseriate rays. $\bullet$ Scale bars: $\mathrm{A}, \mathrm{B}-500 \mu \mathrm{m}, \mathrm{C}-1 \mathrm{~mm}, \mathrm{D}, \mathrm{F}-100 \mu \mathrm{m}, \mathrm{E}-200 \mu \mathrm{m}$, $\mathrm{G}-20 \mu \mathrm{m}$. 

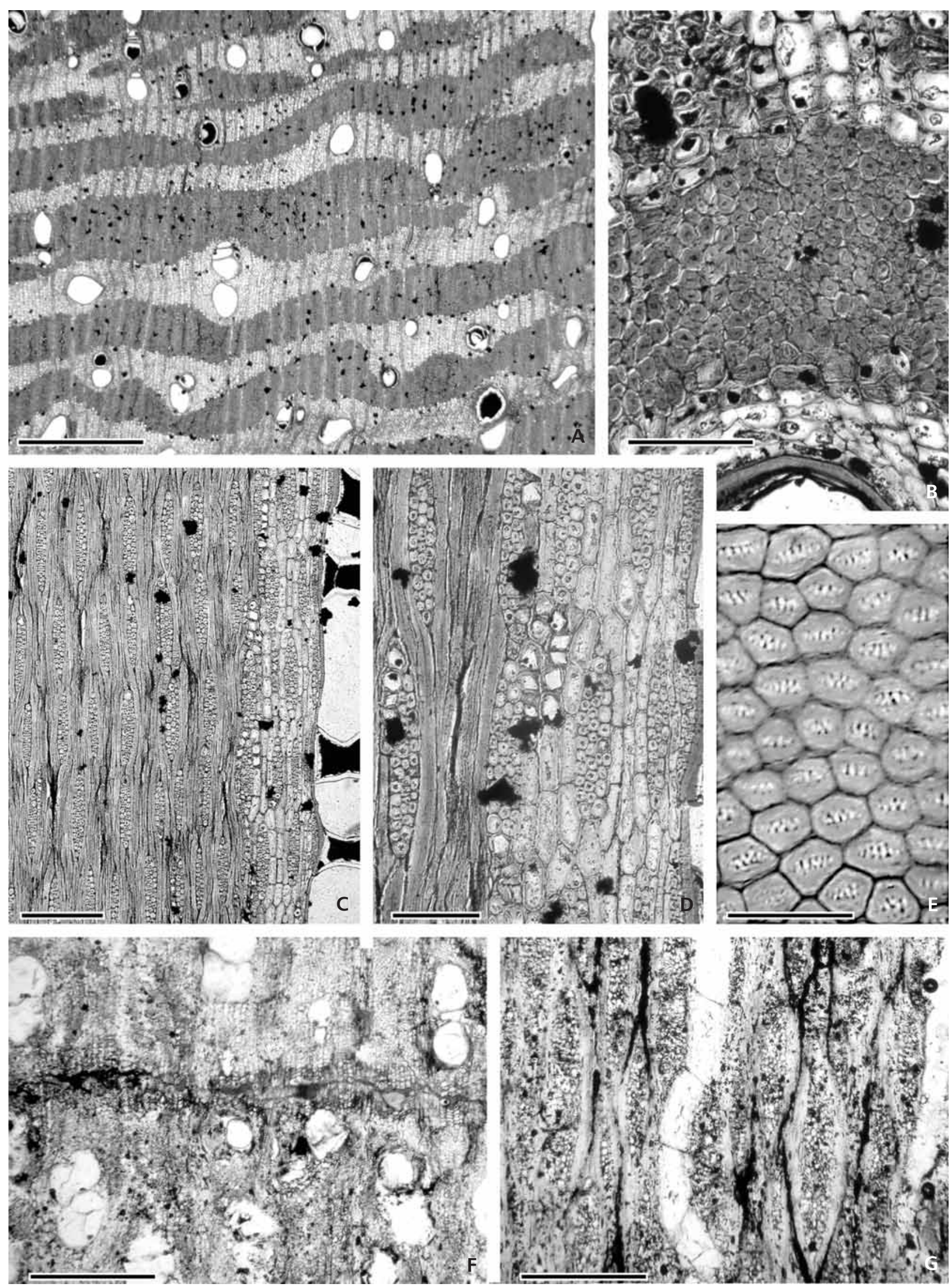

f.

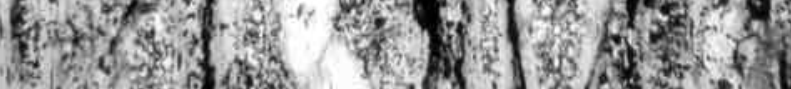

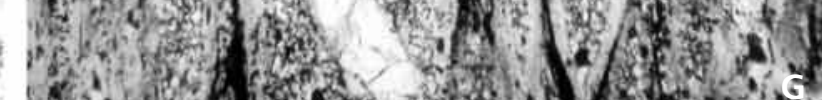


latewood, intervessel pits medium sized, scanty vasicentric and diffuse parenchyma, slightly heterocellular bi-triseriate rays, and axial intercellular canals in a tangential row embedded in axial parenchyma bands. This wood resembles Cedrela P. Br. (Fig. 6D-F), but the fossil shows narrower growth rings than those usually observed in some modern species of Cedrela (Fig. 6G, H). Dünish \& Baas (2006) mentioned the presence of intercellular canals in Cedrela odorata and $C$. fissilis in a significant percentage of the examined samples of old trees.

\section{Incertae sedis}

Figure 5F, G

A wood sample shows distinct growth rings marked by marginal parenchyma bands. Vessels solitary or in radial multiple of $2-4,10-13 / \mathrm{mm}^{2}$ of mean tangential diameter of $100-150 \mu \mathrm{m}$; intervessel pits polygonal, minute; axial crystalliferous parenchyma irregularly diffuse among the fibrous elements of the wood, and scanty paratracheal to vasicentric; marginal bands of parenchyma with traumatic canals; rays homocellular with one row of upright or square marginal cells containing often prismatic crystals; fibres thin- to thick- walled (apparently non-septate?). It closely resembles the modern Meliaceae (Carapa) and Rutaceae (Balfourodendron, Esenbeckia, Zanthoxylum, etc.). The size and the density of the vessels show a greater resemblance with Meliaceae.

Four other samples from the Pebas Formation and one from the Amazonas Formation could not be assigned to a precise modern dicotyledonous family, because of the lack of diagnostic character.

\section{Phytogeography and palaeoenvironment}

All the fossil taxa of the Miocene Pebas Formation belong to genera and/or families present in Amazonia today (see Table 1). According to the present distribution of the observed species in Amazonia (Hueck 1972, Hueck \& Seibert 1972, Schnell 1987, Gentry \& Ortiz 1993, Mabberley 2002), this palaeofloristic assemblage from the upper Pebas Formation can be compared with the modern flora of the lowland rainforest called Amazon hylaea ("Hylaea Amazonia"). Some genera of the Leguminosae,
Lecythidaceae, Humiriaceae and Meliaceae occurring in the Pebas Formation are typical of the "terra firme" forests, especially in the area close to the Amazon delta today. This corresponds to a climate with high and regular rainfall throughout the year (Mean Annual Precipitations - MAP $\geq$ $2500 \mathrm{~mm} /$ year), and a Mean Annual Temperature (MAT) of about 25.5 to $27.5^{\circ} \mathrm{C}$, with a very light annual amplitude (1.5 to $3{ }^{\circ} \mathrm{C}$, Schnell 1987 ).

These taxa, characteristic of "terra firme" forests, were present in South America before the contact between the North and South America. Thus, despite the inevitable taphonomic bias, this sheds some light on the floristic composition of Amazon Basin forests before the contact between North and South America, during the Middle Miocene and even before. South America could have shared floral elements with other Gondwanan continents. Some other families such as Annonaceae, Euphorbiaceae, Lauraceae, Moraceae, Rubiaceae and Sapotaceae, well represented in the modern South American flora, are missing from this fossil assemblage. The number of specimens studied is still not enough to determine whether the aforementioned families were present or absent from South America in Middle Miocene. The Cedrela wood samples from the Pliocene (Amazonas Fm.) reveal a potential environmental change in this area, but the species is also present in the "Hylea Amazonia" in different environments, especially in the recolonization forest types of the river meanders (Puhakka \& Kalliola 1993). This leads to questions of which kind of change occurred between the Miocene and Pliocene of Peru.

\section{Paleaoclimatic signals based on growth ring studies}

The presence of growth rings is usually considered as indicative of a seasonal climate even in the tropics. The annual growth rings are marked by the longest dry season (Détienne 1989, Vetter \& Botosso 1989) and they can be used to estimate the age and growth rate of a tree (Boninsegna et al. 1989). In the tropics, especially in evergreen rain forests, the growth rings are slightly marked by a tangential parenchyma band and/or differences in fibre wall thickness according to the species (Détienne et al. 1998). In some species, growth rings are not obvious or completely undifferentiated.

Figure 6. Meliaceae. $\bullet$ A-C - cf. Guarea. $\bullet$ A - cross section showing vasicentric paratracheal and confluent parenchyma. $\bullet$ B - tangential section with uni-biseriate rays. $\bullet \mathrm{C}$ - detail of a tangential section showing crystalliferous axial parenchyma and rays. $\bullet$ D-H - cf. Cedrela. $\bullet$ D - cross section with distinct growth rings characteristic of seasonal tropical climate. $\bullet \mathrm{E}$ - detail showing a large vessel line in the initial parenchyma. $\bullet \mathrm{F}-\mathrm{cross}$ section with one line of traumatic canals (arrows) between early- and latewood. $\bullet \mathrm{G}$ - Cedrela sp. (extant species, Peru) cross section with a semi ring-porous zone. - H - Cedrela odorata L. (extant species, French Guiana) cross section showing a semi ring-porous zone, with larger and numerous vessels in the earlywood. - Scale bars: A, D, G, H $-1 \mathrm{~mm}, \mathrm{~B}-200 \mu \mathrm{m}, \mathrm{C}-50 \mu \mathrm{m}, \mathrm{E}, \mathrm{F}-500 \mu \mathrm{m}$. 

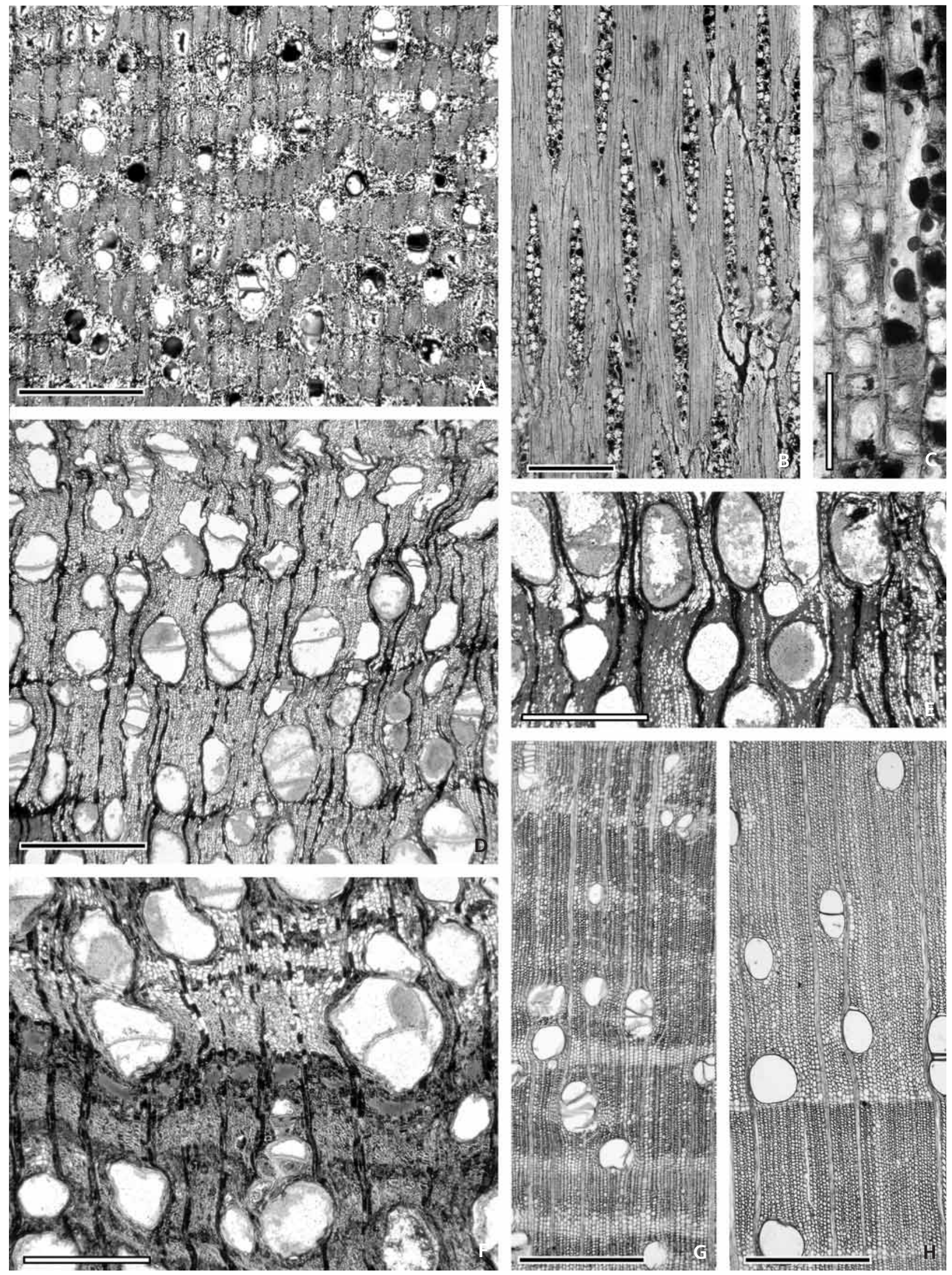
Table 1. Botanical affinities, location of the fossil wood samples, presence of the taxa in the modern flora; growth rings: - absent, (+) weakly marked, + present, ++ semi ring porous.

\begin{tabular}{|c|c|c|c|c|c|c|c|c|c|c|}
\hline \multicolumn{3}{|c|}{ Taxa } & \multicolumn{4}{|c|}{ Fossil data } & \multicolumn{4}{|c|}{ Present distribution } \\
\hline \multicolumn{2}{|c|}{ Family } & Genus & $\begin{array}{l}\text { Number of } \\
\text { specimens }\end{array}$ & $\begin{array}{c}\text { Growth ring } \\
\text { pattern }\end{array}$ & Formation & $\begin{array}{c}\text { Pre-Pliocene presence } \\
\text { in South America }\end{array}$ & $\begin{array}{c}\text { South } \\
\text { America }\end{array}$ & $\begin{array}{c}\text { C\&N tropical } \\
\text { America }\end{array}$ & Africa & $\begin{array}{c}\text { Tropical } \\
\text { Asia }\end{array}$ \\
\hline \multicolumn{2}{|c|}{ Anacardiaceae } & cf. Anacardium & 1 & - & Pebas & + & + & + & - & - \\
\hline \multicolumn{2}{|c|}{ Bignoniaceae } & indet. & 1 & - & Pebas & - & $?$ & $?$ & $?$ & $?$ \\
\hline \multirow{2}{*}{\multicolumn{2}{|c|}{ Clusiaceae }} & cf. Calophyllum & 1 & $(+)$ & Pebas & - & + & + & - & + \\
\hline & & indet. & 1 & - & Pebas & $?$ & $?$ & $?$ & $?$ & $?$ \\
\hline \multirow{2}{*}{\multicolumn{2}{|c|}{ Combretaceae }} & cf. Buchenavia & 1 & - & Pebas & + & + & + & - & - \\
\hline & & cf. Terminalia & 2 & $-/(+)$ & Pebas & + & + & + & + & + \\
\hline \multicolumn{2}{|c|}{ Humiriaceae } & cf. Humiriastrum & 3 & - & Pebas & - & + & + & - & - \\
\hline \multirow{3}{*}{\multicolumn{2}{|c|}{ Lecythidaceae }} & cf. Cariniana & 1 & - & Pebas & + & + & - & - & - \\
\hline & & cf. Echweilera & 1 & $(+)$ & Pebas & - & + & + & - & - \\
\hline & & indet. & 2 & - & Pebas & $?$ & $?$ & $?$ & $?$ & $?$ \\
\hline \multirow{4}{*}{ 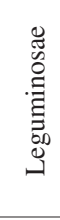 } & Fabaceae & $\begin{array}{l}\text { cf. Andira / } \\
\text { Hymenolobium }\end{array}$ & 1 & - & Pebas & - & + & + & - & - \\
\hline & \multirow{3}{*}{$\begin{array}{l}\text { Mimosaceae- } \\
\text { Ingae }\end{array}$} & cf. Abarema alliance & 1 & $(+)$ & Pebas & - & + & + & + & - \\
\hline & & indet. type 1 & 1 & $-/(+)$ & Pebas & $?$ & $?$ & $?$ & $?$ & $?$ \\
\hline & & indet. type 2 & 1 & $(+)$ & Pebas & $?$ & $?$ & $?$ & $?$ & $?$ \\
\hline \multirow{2}{*}{\multicolumn{2}{|c|}{ Meliaceae }} & cf. Cedrela & 2 & ++ & Amazonas & - & + & + & - & - \\
\hline & & cf. Guarea & 7 & $-/(+)$ & Pebas & - & + & + & + & - \\
\hline \multirow{3}{*}{\multicolumn{2}{|c|}{ Incertae sedis }} & (cf. Meliaceae) & 1 & $(+)$ & Pebas & - & + & - & - & - \\
\hline & & indet. & 4 & - & Pebas & $?$ & $?$ & $?$ & $?$ & $?$ \\
\hline & & indet. & 1 & + & Amazonas & $?$ & $?$ & $?$ & $?$ & $?$ \\
\hline
\end{tabular}

In the wood samples from the upper part of the Pebas Formation, the growth rings are absent or sometimes very slightly marked, except for an incertae sedis sample (cf. Meliaceae), which shows regular traumatic canals in tangential rows. The rarity of strongly marked growth rings is a characteristic feature of low-elevation rain forests. This confirms the conclusion obtained from the botanical affinities of the wood samples.

Growth ring boundaries are not observed in the majority of the samples [Combretaceae, Fabaceae (cf. Andira / Hymenolobium), Lecythidaceae (cf. Cariniana), Meliaceae (cf. Guarea, 6 samples), Mimosaceae]. They are slightly marked in Lecythidaceae, by a faint gradient in vessel size and a wider fibre band in the growth ring limit. In some of the Meliaceae (cf. Guarea) specimens, and in one of the Combretaceae (Terminalia sp. 1) specimens, the growth rhythm is also marked by a regular thin marginal parenchyma band, which could be interpreted as a growth ring boundary. In all samples, the growth seems to be relatively regular (ring width relatively constant). Compared to the modern wood, collected on living trees in this area, the seasons are slightly less marked in the Middle Miocene Pebas Formation woods. This suggests a climate with poorly contrasted seasons (regular rainfall and temperature throughout the year. However, weak growth rings boundaries can still be associated by short dry seasons!).
In contrast, the wood samples from the Amazonas Formation have a semi-ring porous structure. These rings are more or less regular in thickness (about $1 \mathrm{~mm}$ ), and marked by the presence of a decreasing gradient of vessel size. The presence of traumatic axial canals, in 3(or more)-celled marginal parenchyma bands, also underline the growth ring boundaries. This syndrome suggests semi-deciduous to moist deciduous forests for that period, because Cedrela is able to react to alternating seasons by its deciduous phenology. The presence of growth rings in these wood samples is probably a signature of a stronger seasonality, with a more pronounced dry season, in this region during Pliocene. It might also be a response of the trees to a temporary immersion during the rainy season, as it occurs in the "varzea" forest types in lowland rain forests (Hueck 1972, Schnell 1987, Worbes 1989). Nevertheless, overall, the Pliocene is known to have been dryer and warmer than today (Raymo et al. 1996, Haywood \& Valdes 2004) and this could also explain the abundance of Cedrela today. This genus could have colonized the region during a dry period at the end of the Cenozoic. It is now widespread in Central and South America and its expansion and diversification could be dated from the Pliocene, because no record has been reported previously in South America. This should be confirmed by further studies. 
In the context of rapid global climate change, it is crucial to compare in detail the Pliocene flora and vegetation of this region of western Amazonia with the modern highly diversified flora, because a difference of +2 to $+5{ }^{\circ} \mathrm{C}$ has been estimated for Pliocene temperatures compared to the present (Raymo et al. 1996, Haywood \& Valdes 2004).

\section{Acknowledgements}

We thank Michel Lemoine (UMR-CNRS-MNHN 5143) for the preparation of the fossil wood sections. We are grateful to Pierre-Olivier Antoine, who invited us to participate to the "Environnements et CLImats du Passé: hiStoire et Evolution" (ECLIPSE) Program of France, on the History of the Amazon Basin, and to all members of the team of this program, especially Martin Roddaz and Nicolas Espurt for geological information used in this paper. We are extremely grateful to the two reviewers how considerably helped us to improve the final version of this article.

\section{References}

Antoine, P.-O., De Franceschi, D., Flynn, J.L., Nel, A., BABY, P., BENAMMI, M., CALDERON, I. \& ESPURT, N. 2006. Amber from western Amazonia reveals neotropical diversity during the Middle Miocene. Proceedings of the National Academy of Sciences of the United States of America 103(37), 13595-13600.

BALÉE, W. 2000. Qui a planté les décors de l'Amazonie? La Recherche 333, 18-23.

Boninsegna, J.A., Villalba, R., AmARILla, L. \& OCAMPO, J. 1989. Studies on the rings, growth rates and age-size relationships of the tropical tree species in Misiones, Argentina. IAWA Bulletin 10(2), 161-169.

CAMPBELL, K.E. JR. 1996. A new species of giant anhinga (Aves: Pelecaniformes: Anhingidae) from the Upper Miocene (Huayquerian) of Amazonian Peru. Contributions in Science 460, $1-9$.

Davis, S.D., Heywood, V.H., Herrera-Macbryde, O., Villa-Lobos, J., \& HAMILTON, A.C. 1997. Centres of Plant Diversity. A guide and strategy for their Conservation. Vol. 3. 562 pp. The World Wide Fund For Nature (WWF) and The World Conservation Union (IUCN), Gland.

DECHAMPS, R. 1979. Etude anatomique de bois d'Amérique du Sud. I - Acanthacae à Lecythidaceae. Annales du Musée royal de l'Afrique centrale, Séries in- $8^{\circ}$, Sciences économiques 10 , $1-332$.

DECHAMPS, R. 1980. Etude anatomique de bois d'Amérique du Sud. II - Leguminosae. Annales du Musée royal de l'Afrique centrale, Séries in- $8^{\circ}$, Sciences économiques 11, 1-229.

DECHAMPS, R. 1985. Etude anatomique de bois d'Amérique du Sud, III Linaceae à Zygophyllaceae. Annales du Musée royal de l'Afrique centrale, Séries in- $8^{\circ}$, Sciences économiques 15 , $1-471$.
DÉTIENNE, P. 1983. Atlas d'identification des bois de l'Amazonie et des régions voisines. 640 pp. C.T.F.T., Nogent sur Marne.

DÉTIENNE, P. 1989. Appearance and periodicity of growth rings in some tropical woods. IAWA Bulletin 10(2), 123-132.

DÉTIENNE, P., JACQUeT, P. \& MARIAUX, A. 1982. Manuel d'identification des bois tropicaux. 3: Guyane française. 315 pp. C.T.F.T., Nogent sur Marne.

DÉTIENNE, P., OYONO, F., DURRIEU DE MAdRON, L., DEMARQUEZ, B. \& NASI, R. 1998. L'analyse des cernes: application aux études de croissance de quelques essences des peuplements naturels de forêt dense africaine. Série FORAFRI, document 15. 36 pp. CIRAD-Forêt, Montpellier.

DÜNISCH, O. \& BAAS, P. 2006. On the origin of intercellular canals in the secondary xylem of selected Meliaceae species. IAWA Journal 27(3), 281-297.

EVANS, J.E., GASSON, P.E. \& LEWIS, G.P. 2006. Wood anatomy of the Mimosoideae (Leguminosae). IAWA Journal, Supplement $5,1-117$.

Gentry, A.H. \& ORTIZ, R. 1993. Patrones de composición florística en la Amazonia Peruana, 155-201. In KALLIOLA, R., PUHAKKA, M. \& DANJOY, W. (eds) Amazonia Peruana Vegetación húmeda tropical en el subandino. Proyecto Amazónica de la Universidad de Turku y Oficina Nacional deEvaluación de Recursos Naturales. Jyväskylä, Finland.

GROOMBRIDGE, B. 1992. Global biodiversity. Status of the earth's living resources. 585 pp. Chapman \& Hall, London.

HAYwoOd, A.M. \& VALDES, P.J. 2004. Modelling Pliocene warmth: contribution of atmosphere, oceans and cryosphere. Earth and Planetary Science Letters 218, 363-377.

HESS, R.W. 1946. Keys to American woods. XXI. Parenchyma in numerous concentric bands. Tropical Woods 94, 29-52.

HoOghiEMSTRA, H. \& HAMMEN, T. VAN DER 1998. Neogene and Quaternary development of the neotropical rain forest: the forest refugia hypothesis, and a literature overview. Earth-Science Reviews 44, 147-183.

HOORN, C. 1993. Marine incursions and the influence of Andean tectonics on the Miocene depositional history of northwestern Amazonia: Results of a palynostratigraphic study. Palaeoclimatology, Palaeogeography, Palaeoecology 105, 267-305.

HoORN, C. 1994. Fluvial palaeoenvironments in the Amazonas Basin (Early Miocene to early Middle Miocene, Colombia). Palaeoclimatology, Palaeogeography, Palaeoecology 109, 1-54.

HuECK, K. 1972. As florestas da América do Sul: ecologia, composição e importância econômica, 466 pp. Editôra Poligono, S.A., São Paulo.

HuECK, K. \& SEIBERT, P. 1972. Vegetationskarte von Südamerika. Vegetationsmonographien der einzelnen Großräume der Erde IIa. 71 pp. Gustav Fischer Verlag, Stuttgart.

ILIC, J. 1991. CSIRO atlas of hardwoods. 525 pp. Springer Verlag, Berlin.

INSIDEWOOD 2004-onwards. Published on the Internet. http://insidewood/lib.ncsu.edu/search (2007).

KRIBS, D.A. 1968. Commercial foreign woods on the American market. 241 pp. Dover Publ., Inc., New York.

LENS, F., BAAS, P., JANSEN, S. \& SMETS, E. 2007. A search for phylogenetically informative wood characters within 
Lecythidaceae s.l. American Journal of Botany 94(4), 483-502.

MABBERLEY, D.J. 2002. The plant-book. $2^{\text {nd }}$ edition. 858 pp. Cambridge University Press, Cambridge.

MAINIERI, C. \& CHIMELO, J.P. 1989. Fichas de características das madeiras brasileira. $2^{\text {nd }}$ ed. 148 pp. IPT, São Paulo.

MetCAlfe, C.R. \& CHALK, C. 1950. Anatomy of the dicotyledons. 1500 pp. Clarendon Press, Oxford.

PereirA, J.A. \& MAINIERI, C. 1957. Madeiras do Brasil sua caracterização, usos communs e índices qualificativos físicos e mecânicos. 170 pp. IPT, São Paulo.

PUHAKKA, M. \& KALLIOLA, R. 1993. La vegetación en areas de inundación en la Selva baja de la Amazonia Peruana, 111-138. In Kalliola, R., PUhaKKa, M. \& DANJOY, W. (eds) Amazonia Peruana - Vegetación húmeda tropical en el subandino. Proyecto Amazónica de la Universidad de Turku y Oficina Nacional de Evaluación de Recursos Naturales. Jyväskylä, Finland.

RAYMO, M.E., Grant, B., HoRowitz, M. \& RAU, G.H. 1996. Mid-Pliocene warmth: stronger greenhouse and stronger conveyor. Marine Micropaleontology 27, 313-326.

RECORD, S.J. 1943a. Keys to American woods. IV. Vessels virtually all solitary. V. Vessels with spiral thickenings. Tropical Woods 73, 23-33.

RECORD, S.J. 1943b. Keys to American woods. VII. Vessels with very fine pitting. Tropical Woods 74, 31-43.

RECORD, S.J. 1943c. Keys to American woods. X. Woods with storied structure. Tropical Woods 76, 32-47.
RECORD, S.J. 1944a. Keys to American woods. XI. Woods with resin or gum ducts. XII. Parenchyma reticulate. Tropical Woods 77, 18-38.

RECORD, S.J. 1944b. Keys to American woods. XIII. Woods with septate fibers. Tropical Woods 78, 35-45.

RECORD, S.J. 1944c. Keys to American woods. XIV. Dicotyledonous wood with xylem rays virtually all uniseriate. Tropical Woods 79, 25-34.

RECORD, S.J. \& HESS, R.W. 1972. Timbers of the new world (reprint). 640 pp. Arno Press, New York.

Roddaz, M.T., BABy, P., Brusset, S., HermozA, W., \& DARROZES, J.M. 2005. Forebulge dynamics and environmental control in Western Amazonia: the case study of the Arch of Iquitos (Peru). Tectonophysics 399, 87-108.

SCHNELL, R. 1987. La flore et la végétation de l'Amérique tropicale. 480 pp. Masson, Paris.

VetTeR, R.E. \& Botosso, P.C. 1989. Remarks on age and growth rate determination of Amazonian trees. IAWA Bulletin 10(2), 133-145.

VLIET, G.J.C.M. VAN 1979. Wood anatomy of the Combretaceae. Blumea 25, 141-223.

WHEELER, E.A., BASS, P. \& GASSON, P.E. (eds) 1989. IAWA List of microscopic features for hardwood identification. IAWA Bulletin 10(3), 219-332.

WORBES, M. 1989. Growth rings, increment and age of trees in inundation forests, savannas and a mountain forest in the neotropics. IAWA Bulletin 10(2), 109-122. 